Review

\title{
Continental Collision Structures and Post-Orogenic Geological History of the Kangerlussuaq Area in the Southern Part of the Nagssugtoqidian Orogen, Central West Greenland
}

\author{
Jon Engström ${ }^{1, *}$ and Knud Erik S. Klint ${ }^{2}$ \\ 1 Geological Survey of Finland, P.O. Box 96, SF-02151 Espoo, Finland \\ 2 Geological Survey of Denmark and Greenland, Øster Voldgade 10, DK-1350 Copenhagen K, \\ Denmark; E-Mail: kesk@geus.dk \\ * Author to whom correspondence should be addressed; E-Mail: jon.engstrom@gtk.fi; \\ Tel.: +358-29-503-2624; Fax: +358-29-503-2901.
}

External Editors: Ken McCaffrey and Jesus Martinez-Frias

Received: 29 August 2014; in revised form: 23 November 2014 / Accepted: 2 December 2014 / Published: 10 December 2014

\begin{abstract}
Deep-seated continental collision sutures, formed at a depth of more than $20 \mathrm{~km}$, are exposed near Kangerlussuaq, close to the Greenland ice cap, on the southern margin of the Nagssugtoqidian orogen in Central West Greenland, thus offering a rare opportunity to study the tectonic deformation style of such an orogen. This paper adds new information on the tectonic history of the southern flank of the Nagssugtoqidian orogen. It focuses on (1) the results of a detailed structural investigation of lineament zones revealed from remote sensing of geophysical and topographic data and aerial photo interpretation, (2) detailed geological mapping at key locations and (3) a tectonic structural model describing the geological development of the area. The area has undergone several episodes of deformation, which have been compiled into an event succession that recognizes eight tectonic events overprinting each other: Two stages of folding (F1 and F2) have been identified along with one major episode of intrusion of the Kangâmiut mafic dyke swarm $(2.05 \mathrm{Ga})$ into the Archaean continent. These dyke intrusions are very important, since by examining the style of deformation for these intrusions it is possible to define the transition from the North Atlantic Craton in the south to the mobile belts in the Nagssugtoqidian orogen in the north. Five different types of pronounced lineaments and one less pronounced lineament post-dating the Kangâmiut dykes extending from ductile deformation shearing events to brittle deformation with extensive faulting. These lineaments cover both the collisional and post-collisional
\end{abstract}


tectonic history of the area. The study focused on two types of lineaments: one semi-ductile type trending E-W with a dextral sense of shear and a second, a pronounced lineament outlining the Kangerlussuaq-Russell thrust fault. These two features are interpreted to be related to the Nagssugtoqidian orogeny, while the latter lineaments have a more brittle appearance and are regarded to be considerably younger and probably related to post-orogenic tectonic events.

Keywords: continental collision structures; Kangerlussuaq-Russell thrust fault; tectonic structural model; Nagssugtoqidian orogeny; West Greenland

\section{Introduction}

The Nagssugtoqidian orogeny of West Greenland mainly occurred between 1.92 and $1.75 \mathrm{Ga}$ [1], as a consequence of the convergence and collision of the North Atlantic Craton and a poorly defined craton to the north [2]. The Palaeoproterozoic reworking during the orogeny extends from Kangerlussuaq to southern Disko Bugt [3-5]. Several studies have been performed in the central and northern areas of the Nagssugtoqidian orogen (e.g., $[1,6]$ ), while the southern end of the orogen at the northern margin of the North Atlantic Craton, in the proximity of Kangerlussuaq, has largely remained unexplored. However, since 2008, the international Greenland Analogue Project (GAP) has been conducting intensive research in the area around Kangerlussuaq [7]. The main goal of the GAP has been to investigate the deep groundwater in a glaciated terrain. In order to study and model the hydrogeology, a detailed geological investigation and a conceptual geological 3D model of the fault/fracture zones was required. The GAP also drilled three cored boreholes in the vicinity of the ice margin, which provided data for the $3 \mathrm{D}$ geological interpretation. The geological survey revealed a number of structures formed in a plate tectonic collision zone, and the main goal of this paper is to add complementary information to aid in understanding the formation of the Nagssugtoqidian orogen in central West Greenland.

\section{Background: The Development of the Nagssugtoqidian Orogen and the Study Area}

The Nagssugtoqidian orogen is interpreted as a collisional orogenic setting where juvenile Palaeoproterozoic igneous rocks intruded Archaean units and where Palaeoproterozoic sedimentary volcanic rocks were deposited. The orogen is now seen as an approximately $250-\mathrm{km}$-wide, south- to southeastward-trending belt that includes diverse Archaean and Palaeoproterozoic rocks affected by polyphase deformation and high-grade metamorphism [8]. Along the northern margin of the North Atlantic craton, within the southern Nagssugtoqidian orogen, Archaean dioritic, granodioritic, tonalitic and granitic orthogneiss of the North Atlantic craton predominate, albeit in a reworked state [2,9-12]. The orthogneisses have been dated to $2.87-2.81 \mathrm{Ga}$, with the plutonic protoliths deformed and metamorphosed between 2.81 and $2.72 \mathrm{Ga}$, immediately after their emplacement [11,12]. The orthogneisses are cut by several sets of mafic dykes, the most voluminous of which is the E-W- to NE-SW-trending, 2.05-2.04 Ga Kangâmiut dyke swarm [13-21]. The Kangâmiut dyke swarm, which extends from the Archaean foreland into the centre of the orogen, has become reworked across a sharp transition at the southern 
Nagssugtoqidian front. Its northern extent is abruptly terminated by the Ikertoôq thrust zone (Figure 1), which is a south-vergent ductile shear zone [2]. Dykes from the Kangâmiut swarm occur in the Archaean gneiss complex for approximately $150 \mathrm{~km}$ south of the thrust zones traditionally taken as marking the southern Nagssugtoqidian front in SW Greenland, and continue as deformed bodies in the reworked Archaean gneisses for approximately $50-100 \mathrm{~km}$ to the north of the front [17].

The granulite-facies thermal peak of metamorphism in the core of the orogen was dated at $c a$. 1.86-1.84 Ga $[11,20,22,23]$. This age interval coincides with the timing of thrusting and is interpreted as documenting the main phase of collision across the Nagssugtoqidian orogen. The Nagssugtoqidian orogen is interpreted as being associated with the closure of two south-dipping Palaeoproterozoic sutures [6,24,25]: (1) a northern suture, the Disko Bugt suture, which separates the lower plate Rae craton from the middle Aasiaat domain; and (2) a southern suture rooting in the Nordre Isortoq steep belt that separates the southerly-located North Atlantic Craton from the Aasiaat domain [26]. This model was further developed by Garde and Hollis [1], who concluded there are two south- to SSE-dipping subduction zones in the central and northern Nagssugtoqidian orogen, which were separated by the previously unidentified Aasiaat domain or microcontinent.

Figure 1. (A) Geological map of the central West Greenland and the Nagssugtoqidian orogen, indicating the location of Kangerlussuaq. Map modified from van Gool et al. [2]. (B) A lineament and geological map of the study area, in front of the Greenland ice sheet. Map modified from Garde and Marker [27].

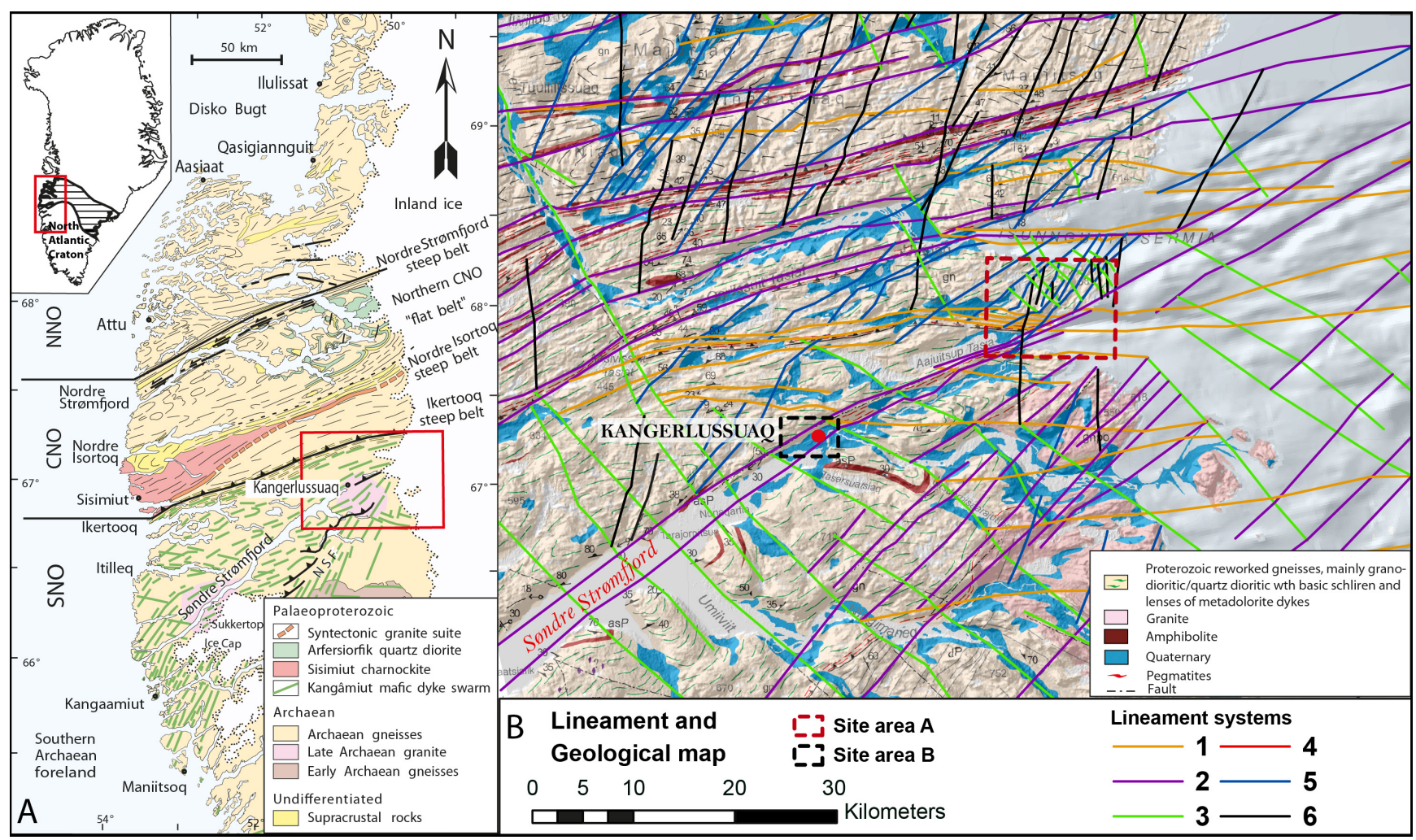

The Study Area

The study area is located at the southern end of the orogen in the vicinity of the North Atlantic Craton (Figure 1). It covers a domain of $60 \mathrm{~km} \times 80 \mathrm{~km}$ with a special focus on an area at the front of the 
Greenland ice sheet (Figure 1A). Most of the mapping, including the drilling of three deep boreholes, was conducted in area A (Figure 1B) during field campaigns in 2008-2009, while area B was surveyed during mapping campaigns in 2010-2011. A geological 3D model close to the boreholes was constructed for groundwater modelling purposes. The mapping at other locations primarily focused on the nature of the lineaments and their crosscutting relations in order to identify lineaments with potential for hydraulically conductive fractures/faults. A preliminary geological event succession based on lineament interpretation of the area was presented by Klint et al. [28] in 2013, complementary data were collected in the field, and this paper presents an updated geological model of the Kangerlussuaq area.

The study area, extending from Kangerlussuaq Airport to the ice sheet, is dominated by primarily felsic banded gneisses and mafic garnet-rich orthogneisses, intruded in places by pronounced 1-25-m-wide Kangâmiut dykes, especially in the southwestern part of the study area. Detailed geological mapping focused on selected sites from Kangerlussuaq Airport to the margin of the ice sheet (Figures 1B and 2). The Nagssugtoqidian structures reflect the general ductile nature of the regional deformation and include a penetrative gneissic fabric, macro-scale folds, and evidence of shearing in pronounced shear zones. Brittle structures such as faults and fractures are abundant and were probably formed in a younger, shallow, colder and hence more rigid environment.

Figure 2. Geological map illustrating the distribution of the lineaments in the ice-margin valley area as well as the main general structures and rock fabric. Seven key locations were investigated in 2011 and three more (Figures 3-5) in 2013. The key locations described below are highlighted along with the different lineament systems defined by Klint et al. [28].

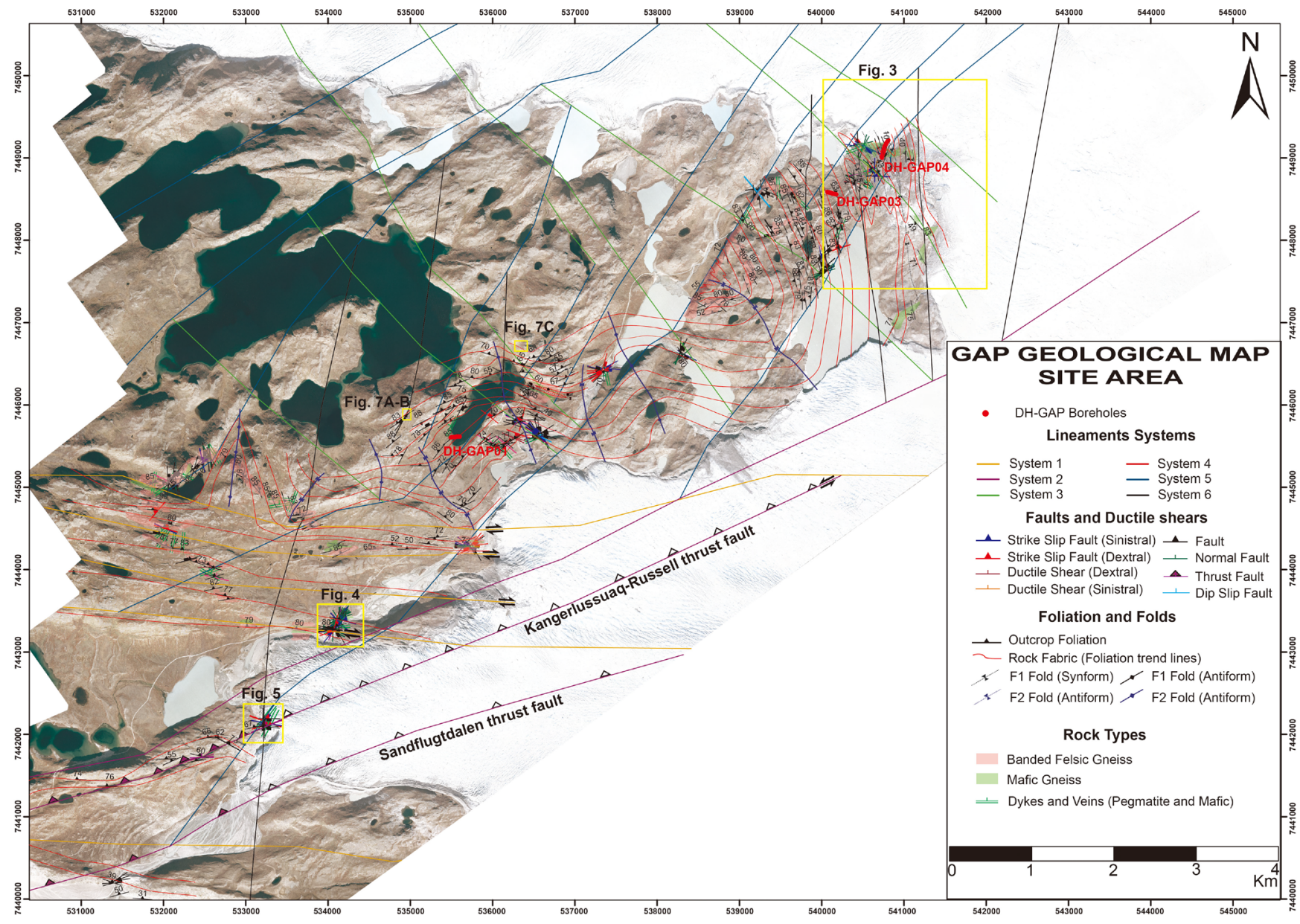


Figure 3. Geological map illustrating the geology around the two boreholes, DH-GAP03 and DH-GAP04. The cross-section illustrates how the folding pattern changes from a larger open fold in the E towards tight to isoclinal folding in the $\mathrm{W}$. The same can be observed in the stereographic plots.

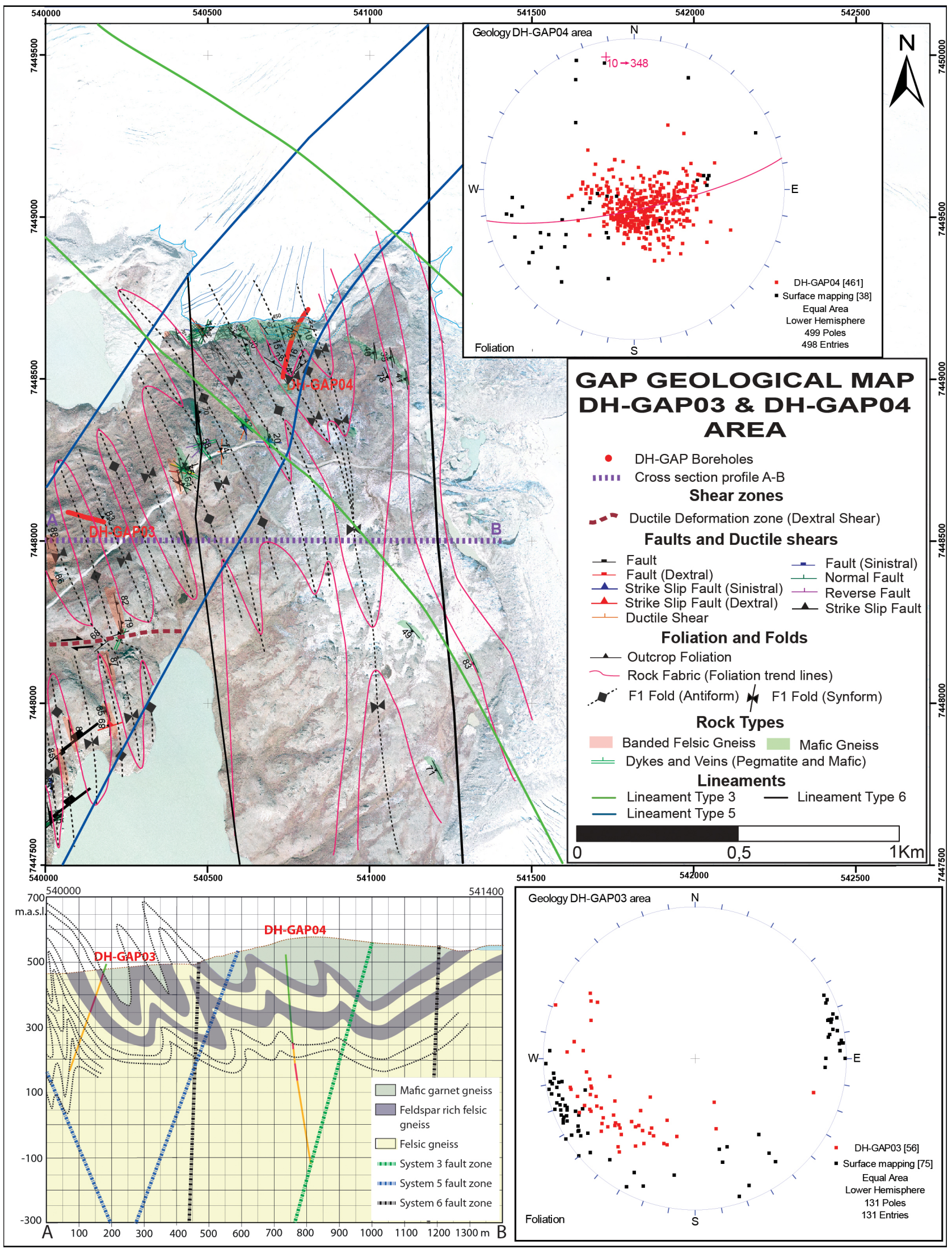


Figure 4. Location B. Overview of the BBQ location. Detailed measurements of faults and fractures were conducted along 3 transects, BBQ 1-3. Selected outcrops with structures showing cross-cutting relationships were measured and the event succession of the structures was evaluated.

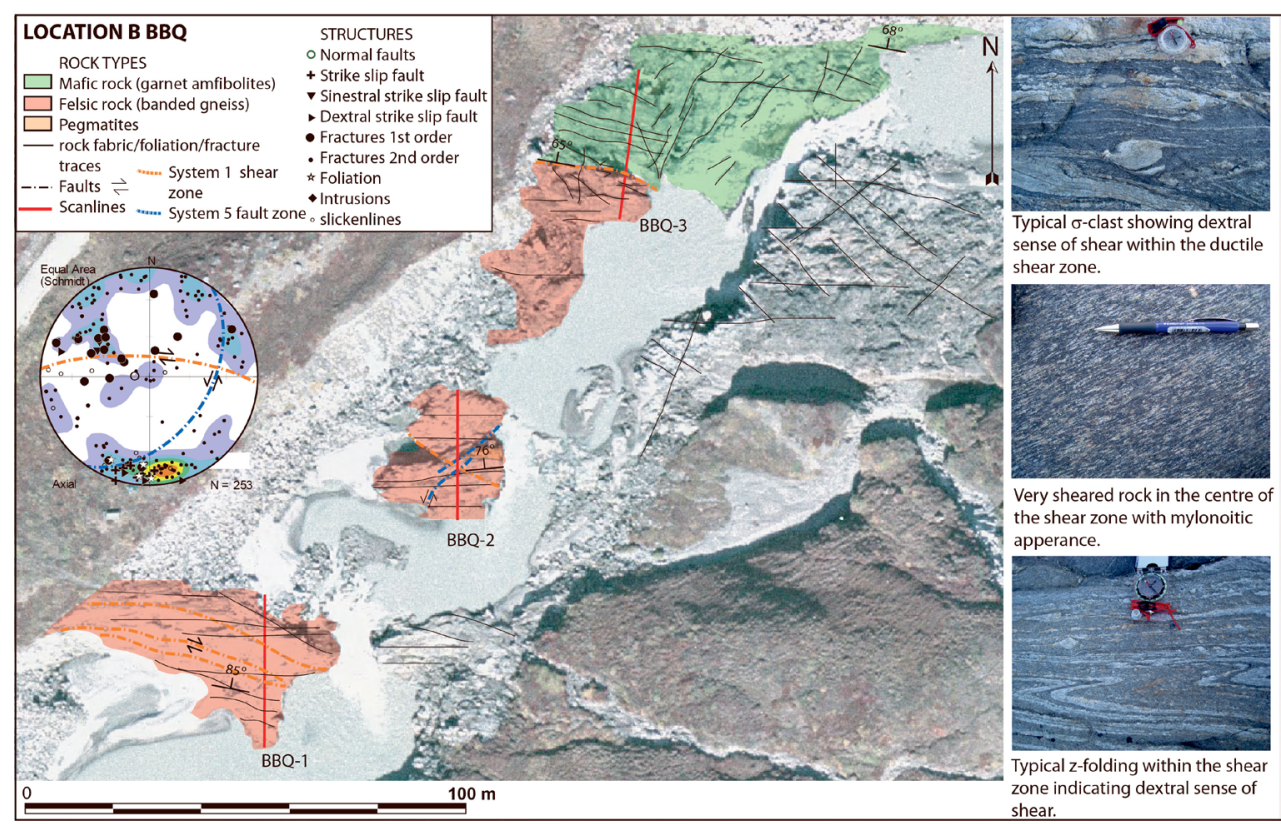

Figure 5. Cross-cutting relations of systems 1, 2 and 5, and deformation style. (A) Intensely deformed gneiss with inclusions of mafic rocks of unknown origin. (B) Banded felsic and mafic gneiss truncated by pegmatites. (C) A folded Kangâmiut dyke. (D) System 5 sinistral strike-slip faults with syntectonically formed pegmatites. (E) The fault core in the Kangerlussuaq-Russell thrust fault. Multiple thrust planes and crushed zones with fault gauge.

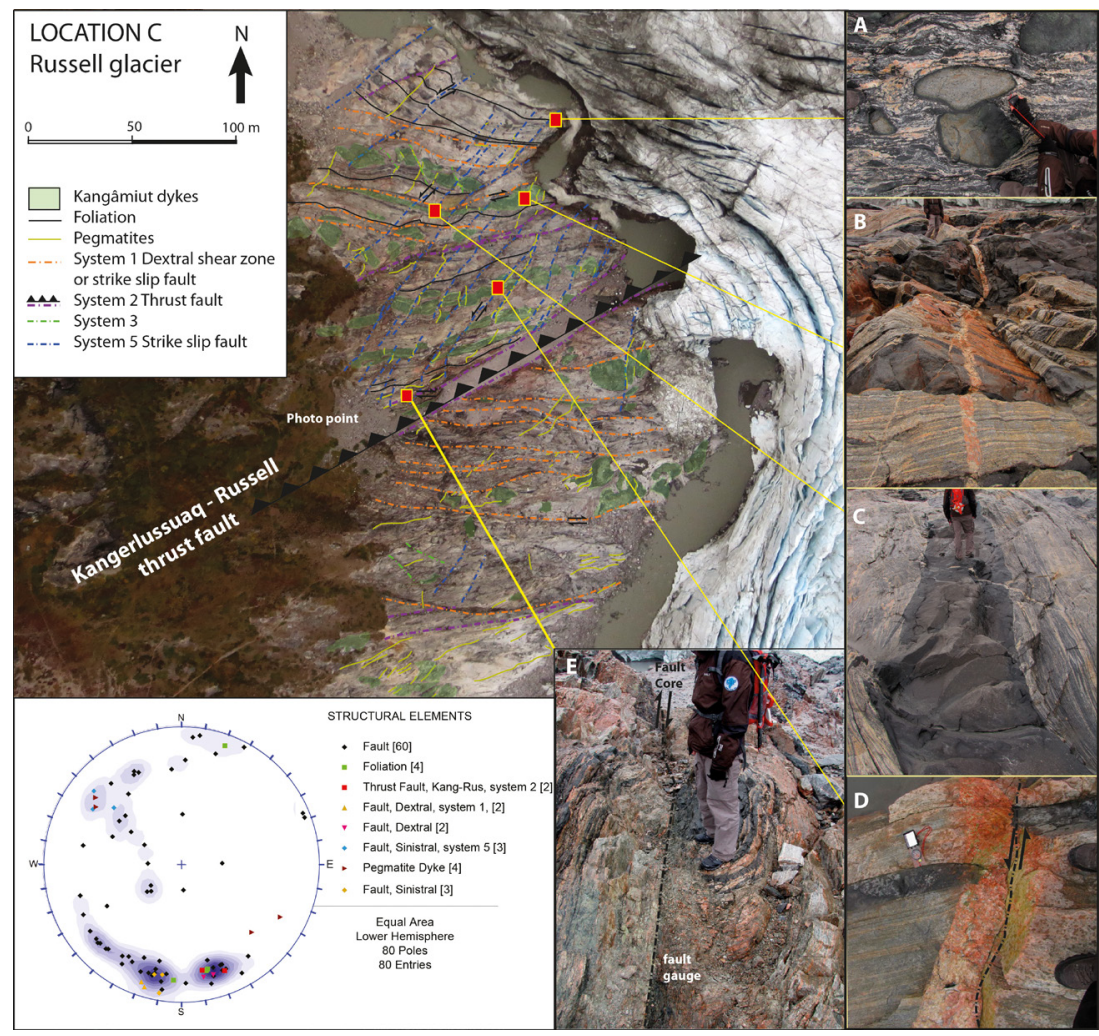




\section{Regional Lineament Mapping}

Most lineaments in crystalline rocks represent structural features such as faults, shear zones, rock fabric, or less competent zones reflecting differences in rheology. Lineament mapping generally comprises three steps: (1) identification of lineaments using remotely sensed GIS data compiled from aerial photographs, together with topographical, geological and geophysical data; (2) selection of lineaments and verification of their nature and individual cross-cutting relations in the field (descriptive and kinematic analysis); and finally (3) the development of a local event succession model by determining overprinting relationships [28].

According to Klint et al. [28], five lineaments primarily representing fault zones were outlined from the GIS analysis (systems 1, 2, 3, 5, 6). The subsequent fieldwork in 2011 confirmed these lineaments, and also identified a sixth sub-horizontal fault system (system 4). The curvilinear nature of the foliation traces highlighting the superposition of two stages of folding (F1 and F2) was also investigated (Figure 2).

During the fieldwork in 2013, cross-cutting relations between the different lineament systems were established and the major lineament extending from Kangerlussuaq to the Russell Glacier, hereafter the Kangerlussuaq-Russell thrust fault, was mapped in more detail.

The lineaments were correlated by Klint et al. [28] as follows:

System 1 lineaments (orange) are orientated E-W with a steep dip towards N (Figure 2). Locally, these lineaments dominate the southern part of the field area and consist of ductile E-W-trending, locally 10-100-m-wide, foliation-parallel, steeply N-dipping dextral shear zones (Figures 2 and 4). During the semi-ductile shearing of these steep zones, it is recognised that Kangâmiut mafic dykes were sheared and deformed, thus indicating that these shear zones are younger than the 2.05-2.04 Ga Kangâmiut dyke swarm [21]. Immediately north of the study area, the prominent Ikertoôq thrust zone has been described by van Gool et al. [2] and Grocott [29]. It is described as a two-phased deformation zone or shear belt with the superposition of two differently orientated simple shear strains. The earlier simple shear strain initiated the shear belt and was characterized by horizontal ENE-WSW movements in a vertical shear plane. The second deformation was produced by over-thrusting in a SSE direction [29]. The system 1 lineaments in this area are interpreted to be similar to these shear belts further north, showing the same deformation style as the first phase of deformation in the thrust zone further north.

System 2 lineaments (lilac) are the most pronounced lineaments in the study area. They represent regional SW-trending shear zones, including two zones that parallel each other. The first of these is presently occupied by Søndre Strømfjord and stretches along the northern margin of Sandflugtdalen (translated as the Sand drift valley), hereafter named the Sandflugtdalen thrust fault. The second one is situated to the north, stretching from Kangerlussuaq to the Russell Glacier, hereafter named the Kangerlussuaq-Russell thrust fault (Figure 2). Further north (Figure 1A), Nordre Isortoq and Nordre Strømfjord steep belts [2] outline similarly oriented lineaments. In the Kangerlussuaq-Russell thrust fault, this lineament is dominated by dextral strike-slip movement overprinting elements of thrust faulting dipping towards the north. Large boudins of deformed Kangâmiut mafic dykes [21] are cross-cut by this fault zone, which is accordingly younger than the intrusion of the Kangâmiut dykes. The second deformation event in the Ikertoôq thrust zone was produced by thrusting towards SSE [29], which is similar to the thrusting occurring in the Kangerlussuaq-Russell thrust fault. 
System 3 lineaments (green) are a major system trending NW, outlining pronounced valleys all the way up to Aassiaat and the Disko Bay. Locally within this area, they form semi-brittle sinistral strike-slip fault zones that displace the system 1 shear zones.

System 4 (red) forms oblique to subhorizontal fracture systems trending NNE and not represented by any pronounced lineaments. These structures may also be related to a population of normal faults and younger NNE-trending pegmatites oriented parallel with the normal faults. They overprint system 1 and 3 structures, but no cross-cutting relationship with system 2 structures has been observed.

System 5 (blue) generally consists of semi-brittle sinistral strike-slip faults trending NE and dipping towards NW or SE. This system outlines the pronounced escarpment in the central-northeastern corner of the area (Figure 2). Locally, zones of thrust faulting striking WSW and dipping north and south are regarded to represent local transpression in a wrench fault system related to the overall system 5 lineaments [30]. This system is often related to pegmatites, which strike parallel to the faults.

System 6 (black) outlines N-S-trending brittle dextral strike-slip faults. This system may be related to system 5 as a conjugate system. The age of this deformation is questionable; however, lineaments with the same orientation near the west coast have been related to young tectonic events during the rifting between Greenland and Canada that took place during the last $100 \mathrm{Ma}$ [30].

\section{Field Observations from Site Areas A and B}

The Kangerlussuaq area may be separated into two subregions: the ice margin valley (site area A) and the Kangerlussuaq Airport area (site area B) (Figure 1B).

The mapped and interpreted structures (foliations, folds, hinge lines, faults and shear zones) are shown on a high-resolution aerial image to provide an overview of the geological framework of the study area (Figure 2). Close to the ice sheet margin, in the northeastern part of the area, the bedrock is characterised by folded mafic garnet gneiss that defines an open, NNW-trending and shallowly plunging $\left(\mathrm{ca} .10^{\circ}\right) \mathrm{F} 1$ fold structure. The F1 folds gradually turn into tight/isoclinal steeply dipping overturned folds that can be traced south and westward around an open and steeply plunging, kilometre-scale F2 fold structure with a steeply dipping fold axis $\left(c a .70-60^{\circ}\right)$ towards N-NW. The large-scale F2 fold structures are repeated several times going from east to west in the northern part of the study area. However, the southern part of the study area is dominated by the aforementioned (orange) E-W-trending lineaments, forming 10-100-m-wide foliation-parallel semi-ductile shear zones. The rock type to the west and south is mainly felsic orthogneiss with varying amounts of garnet. The 10-100-m-wide foliation-parallel shear zones (orange lineaments) are believed to be syntectonic with the formation of the F2 folding, and these shear zones may have acted as the decollemént plane for the folding. A few key locations (locations A, B, C and D) were mapped in detail to enhance knowledge of the geology and to determine the cross-cutting relationships.

\subsection{Location A: Geology around Boreholes DH-GAP03 and DH-GAP04; F1-F2 Folding, System 3, 5} and 6 Lineaments

The area close to location A has been subjected to multiple phases of folding, where the F1 folds usually have a tight to isoclinal pattern. This pattern is widely distributed over the northern part of site area A, except in the northeastern part, where the structures are dominated by an open F1 fold in mafic 
garnet gneiss (Figure 3). This fold shallowly plunges $\left(\mathrm{ca} .10^{\circ}\right)$ towards NNW. It has been recognised as a structure extending down into the bedrock, as demonstrated by the deepest research borehole (DH-GAP04), showing that the fold extends to a vertical depth of at least $650 \mathrm{~m}$. To the west, this shallowly plunging fold turns into a tight/isoclinal folding pattern with several standing/overturned folds having a wavelength of approximately $50-100 \mathrm{~m}$, stretching over a $0.5-\mathrm{km}$-wide area around DH-GAP03 (Figure 3). These folds also steeply plunge towards NNW, and south of DH-GAP03 they are intersected by an E-W-trending 50-100-m-wide ductile shear zone with a dextral sense of shear (Figure 3).

Further to the southwest of this area, the F1 folds gradually turn into an open and steeply-plunging, kilometre-scale F2 fold structure with a WNW-trending axial plane (Figure 2). Further west, the F2 folding is more frequent and also becomes tighter, and furthest to the west the folds are tight to isoclinal, overturned and tilted towards E, and with the fold axis dipping steeply towards N-NW (Figure 2).

\subsection{Location B, System 1 and 5 Lineaments}

Location B is situated in the southern part of the ice-margin valley, which is less folded than the previously described northern part. The area is generally dominated by E-W-trending foliation steeply dipping towards $\mathrm{N}$. The bedrock is truncated by 10-100-m-wide foliation parallel shear zones (orange system 1 lineaments), which are found at varyingly spaced intervals along a 2-km-wide zone (Figure 2). A number of outcrops outlining well-exposed sections of the bedrock are situated in the riverbed following the northern flank of the Russell Glacier. A total of six outcrops were investigated in this riverbed, and for each of them an event succession was outlined in order to reconstruct the tectonic history of the area [28]. Location B was selected to represent the system 1 and 5 lineaments. It is situated in the riverbed close to the Russell Glacier in the southern part of the geological map (Figure 2).

The dominant rock types constitute a sequence of felsic banded gneisses at least $150 \mathrm{~m}$ thick striking $\mathrm{E}-\mathrm{W}$ and dipping $86-65^{\circ}$ towards $\mathrm{N}$. More than $50 \mathrm{~m}$ of primarily mafic rock is exposed in the northernmost part of the location, and the contact between the mafic and felsic rocks is extremely weathered and more densely fractured. Several intrusions in terms of dykes and pegmatite are abundant, but the outcrop is dominated by several E-W-trending shear zones showing an overall ductile deformation style. The shear zones are predominantly situated in the felsic gneiss, and are dominated by foliation-parallel shear, illustrated by Z-shaped drag folds and slickenlines primarily indicating dextral shear movement (Figure 4). The core of the shear zones also occasionally shows mylonites and pseudo-tachylites. Occasional thin foliation-parallel dykes occur in the southernmost part of the area, and near BBQ2 (see Figure 4) a pegmatite intrudes the banded gneiss. This pegmatite is flanked by a NE-SW-trending sinistral strike-slip fault that truncates the system 1 shear zones (and is accordingly younger). These faults are interpreted to belong to the system 5 (blue) lineaments (Figure 4).

\subsection{Location C, System 1, 2 and 5 Lineaments}

At the southernmost end of site area A (Figure 2), in front of the Russell Glacier, a meltwater river has eroded the front of the glacier and removed all the sediments, exposing a $200 \mathrm{~m} \times 400 \mathrm{~m}$ outcrop including a triple junction of three lineaments: systems 1, 2 and 5. High-resolution aerial photos were acquired from the central part of the area, where the Kangerlussuaq-Russell thrust fault continues under the glacier. Deformed felsic and mafic gneisses, as well as intrusions such as the Kangâmiut dykes and 
pronounced pegmatites are clearly distinctive, and single faults and deformation zones are outlined (Figure 5).

The area was mapped in detail during the field season in 2013. Approximately 80 measurements were collected on fault planes, dykes and foliations, and their characteristics were described. Generally, the rock types are dominated by highly deformed banded felsic gneiss (Figure 5A) intercalated with more mafic rocks and a large variety of intruded rock types of various origins and types (Figure 5B). The most conspicuous are the 10-15-m-thick E-W-trending Kangâmiut dykes (Figure 5C) and NE-SW-trending 10-50-cm-thick pegmatites (Figure 5D).

The area may be separated by distinct northern and southern deformation styles, which are separated by the central Kangerlussuaq-Russell thrust fault. The main thrust fault forms a 10-15-m-wide thrust core striking ENE-WSW and dipping $70^{\circ}$ to NNW. The fault core consists of multiple zones with fault gauge and strongly crushed zones, with closely spaced striated fault planes showing a dip slip reverse displacement, mixed with younger sub-horizontal dextral strike slip striations (Figure 5E). The crushing in the fault core has facilitated glacial erosion, forming a valley under the glacier. This valley can be traced in the topography more than $30 \mathrm{~km}$ to Kangerlussuaq. Secondary parallel thrust faults are visible in a 300-m-wide zone north and south of the fault core. Generally, the northern part of the area is less deformed than the southern part. The Kangâmiut dykes are fairly intact, in contrast to the southern area, where the gneiss is more sheared and the Kangâmiut dykes are broken up in large boudins. This is clearly a result of displacement along the Kangerlussuaq-Russell thrust fault, showing a system 1 shear zone displaced in the footwall block and the less deformed basement rocks displaced in the hanging wall block. Finally, system 5 faults striking NW-SE $\left(120-130^{\circ}\right)$ and dipping $70-60^{\circ}$ towards SE truncate all structures, with a general sinistral displacement ranging in the order of $\mathrm{cm}$ to $4-5 \mathrm{~m}$. The spacing of the fault planes is generally homogeneous throughout the northern area, with an average spacing of $2-10 \mathrm{~m}$ between the fault planes.

\subsection{Location D, Kangerlussuaq Area (Site Area B)}

Location D is a large area $(3 \mathrm{~km} \times 4 \mathrm{~km})$ around Kangerlussuaq Airport marked as site area B in Figure 1. Figure 6A presents an aerial image of Kangerlussuaq Airport showing two parallel system 2 thrust faults: the Kangerlussuaq-Russell thrust fault and the corresponding Sandflugtdalen thrust fault, located approximately $1 \mathrm{~km}$ further south. The Sandflugtdalen thrust fault trends parallel with the airport strip, continuing east towards the Russell Glacier through Sandflugtdalen and west towards the Søndre Strømfjord. The Kangerlussuaq-Russell thrust fault forms a very distinct depression containing a number of elongated lakes that are easy to identify on aerial images, whilst the Sandflugtdalen thrust fault is situated in the middle or northern part of the Sandflugtdalen (Sand drift valley), a sediment-filled depression, which makes the exact location of the thrust fault ambiguous.

Despite the fact that the Sandflugtdalen thrust fault is difficult to detect, the significantly different degree of deformation on the $\mathrm{N}$ and $\mathrm{S}$ sides of the thrust fault indicates that a considerable amount of thrusting has occurred along the fault. The area south of the Sandflugtdalen thrust fault exhibits Kangâmiut dykes that are largely undisturbed, with a sub-vertical dip (Figure 6B-D), while the Kangâmiut dykes are strongly sheared (boudinaged) and moderately dip towards N, on the northern side of the valley, especially in the so-called Kitchen Mountain to the north (Figure 6E,F). Field 
investigations have demonstrated that the deformation is initially restricted to system 1 dextral semi-ductile shear zones, later truncated by the system 2 Kangerlussuaq-Russell thrust fault. A later stage of sinistral strike slip deformation occurs in some areas and N-S-trending strike-slip faulting is also observed.

The change in the deformation style of the Kangâmiut dykes is evident when observing them along a regional N-S transect from the folded area in the north (site area A) (Figure 2) and through the strongly sheared system 1 shear zones in the central area, towards the generally undisturbed area south of the Sandflugtdalen thrust fault. The folded area in the north shows Kangâmiut dykes that are mostly undisturbed or in some places were locally folded during the D2 deformation phase (Figure 7), while the area with the system 1 shear zones shows boudinaged and sheared Kangâmiut dykes (Figure 6E,F).

The observations in the Kangerlussuaq area (site area B), coupled with observations further NE in site area A (Figures 1 and 2), suggest that the southernmost end of the Nagssugtoqidian orogen is complex with several geologically different belts or zones having notably different degrees of deformation. The deformation changes from folded areas (Figures 3 and 7) to steep N-dipping semi-ductile shear zones (Figure 4) and steep thrust faulting with a general dip towards NW (Figure 5), with noticeably undisturbed sections in the south (Figure 6).

Figure 6. (A) Aerial image illustrating cross-cutting relationships between system 1 shear zones and system 2 thrust faulting. The Sandflugtdalen thrust fault is the major fault dividing these areas, and it is clear how the Kangerlussuaq-Russell thrust fault truncates the system 1 shear zones, displacing them by several hundreds of metres. (B-D) The southern part of the valley and the Raven Cliff is dominated by weakly deformed Kangâmiut dykes. $(\mathbf{E}, \mathbf{F})$ The northern part of the valley and Kitchen Mountain shows boudinaged Kangâmiut dykes deformed by the system 1 shear zones.

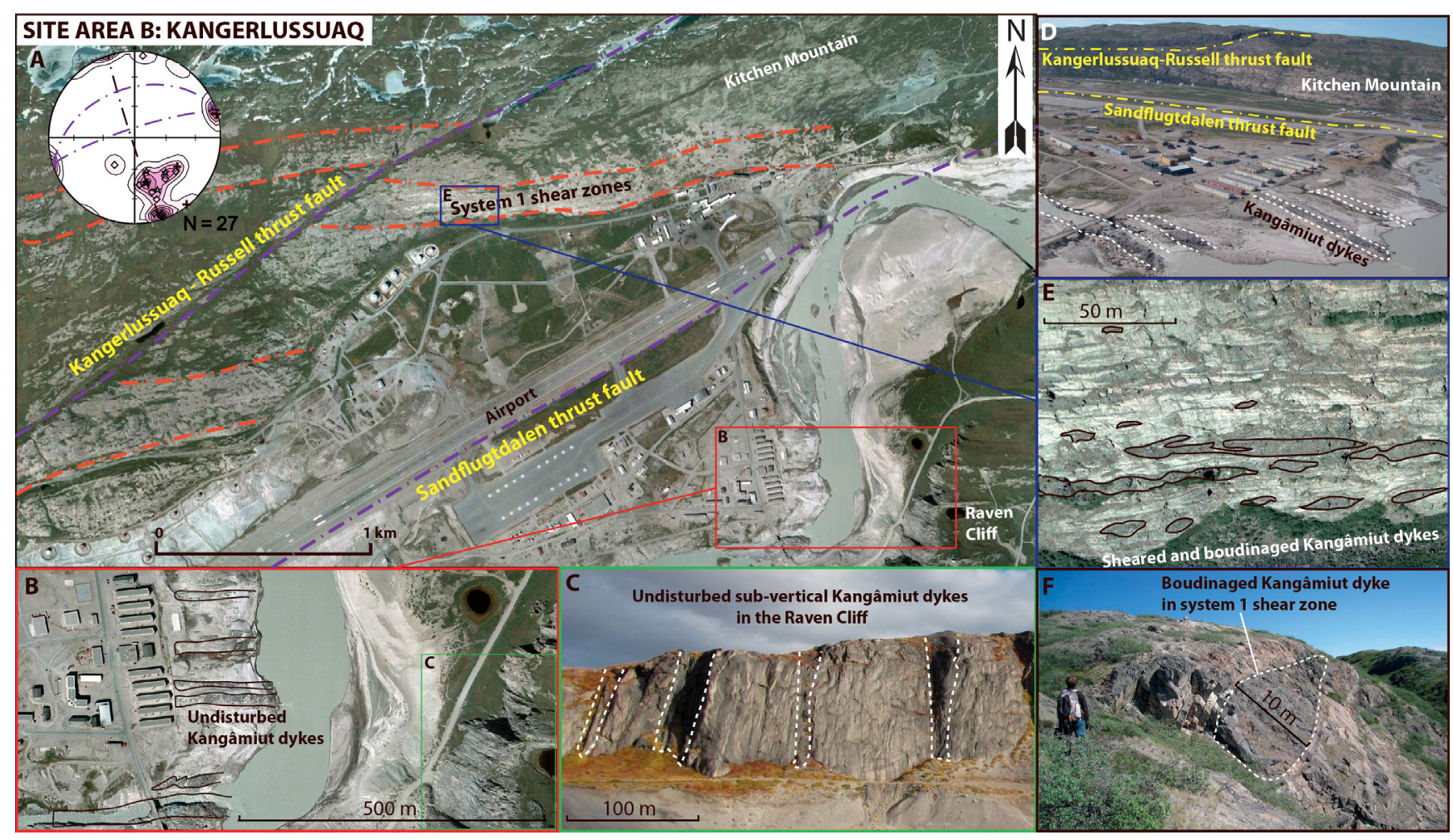


Figure 7. Photos showing the appearance of Kangâmiut dykes in the northern folded area of the study site. (A) Kangâmiut dyke intruded into the bedrock during an extensional strain regime. (B) A folded dyke showing ductile D2 deformation. (C) A large Kangâmiut dyke truncating the F1 folds and slightly folded during D2 deformation.

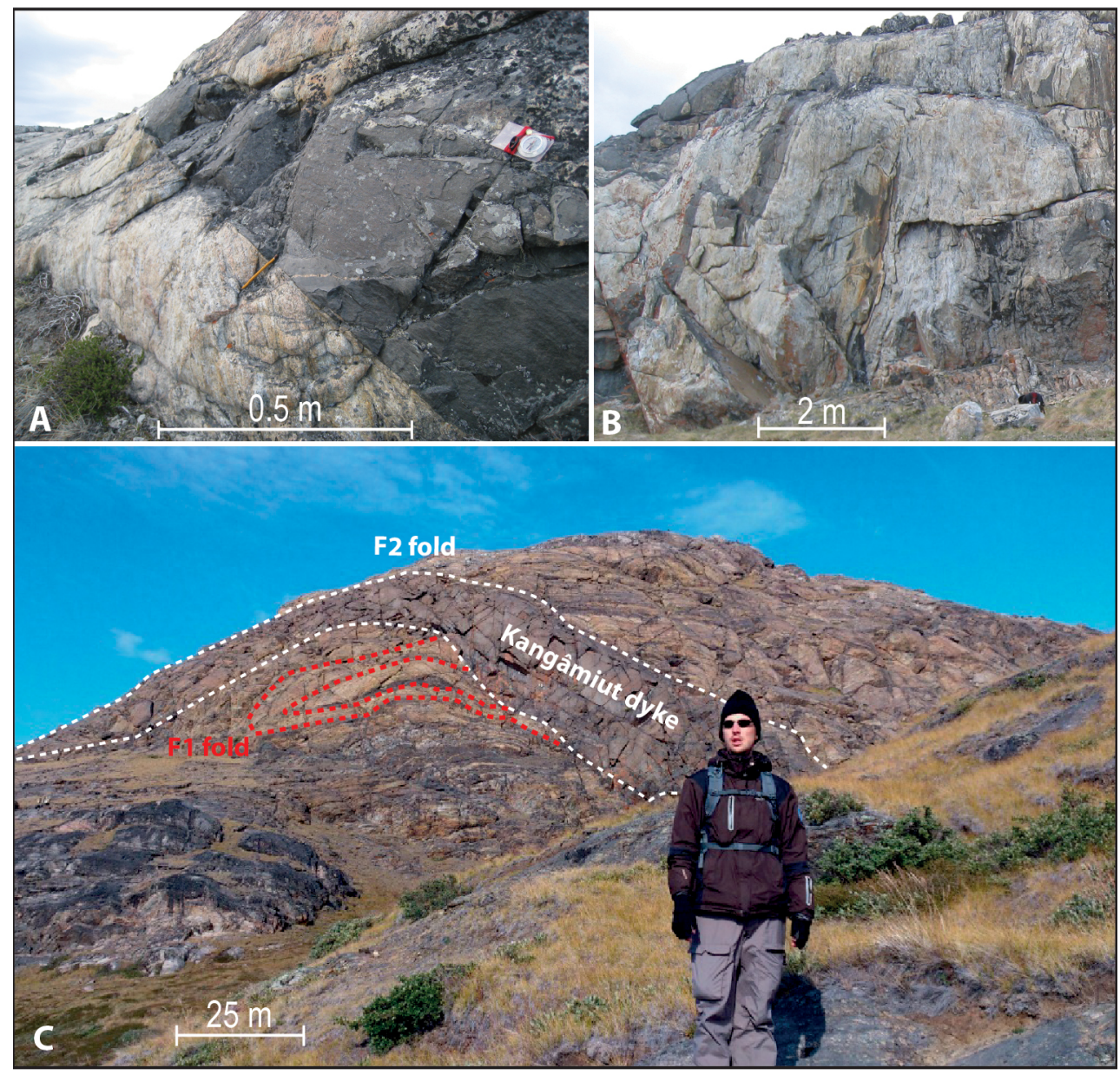

\section{Geological Evolution of the Area}

As demonstrated by its structural complexity, the field area has undergone several phases of deformation, and these phases have been compiled into a schematic model describing the geological evolution of the area. Two stages of ductile deformation, D1 and D2 (folding F1 and F2), have been identified. D1 deformation is considered to be the oldest discernible deformation phase in the area. The Kangâmiut dykes cross-cut the S1 foliation and the related F1 folds (Figure 8), and the intrusion of these dykes is thus a younger event. The second stage of deformation (D2) is the F2 folding phase, which consists of re-folding of the D1 folds. This folding phase also included deformation and folding of the Kangâmiut dykes at several locations, implying that this folding phase post-dates the intrusion of these dykes (Figure 8). Next deformational event comprises the E-W-trending and steeply $\mathrm{N}$ dipping semi-ductile shear zones (system 1). These shear zones are interpreted to be syn-kinematic or contemporaneous with the F2 folding event. It is possible these shear zones may have acted as a decollemént surface for the folding. These shear zones also post-date the Kangâmiut dykes, since these dykes have been deformed and sheared by the shear zones (Figure 8). 
The onset of the brittle deformation (D3 deformation phase) is defined by several ENE-WSW-trending thrusts or reverse faults (system 2). At the southern end of site area A, several of these thrust faults are spaced at regular intervals, building up thrust sheets with a hanging wall thrusted towards SSE (Figure 8). These thrusts cross-cut all the aforementioned features, but they also represent a gradual rotational shift from a general strike-slip-dominated setting (passive plate boundaries) towards classic collisional structures. These thrust faults are especially prominent along the Kangerlussuaq-Russell thrust fault, with a generally moderate to steep dip towards NW. Accordingly, these thrust sheets have been rotated towards a more steeply dipping position from the original location. The system 3, 4, 5 and 6 lineaments show a significantly more brittle character than the previously described deformation phases (Figure 8 ). The system 3 lineaments overprint systems 1 and 2 and the F2 folds. The normal faulting and NNE-trending pegmatites of system 4 indicate either a general extensional stress regime or local transtension during strike-slip movements. Finally, the youngest geological events are related to the type 5 and 6 lineaments, forming two generally brittle strike-slip fault systems, which are also regarded as the primary hydraulic zones in the area.

Figure 8. Schematic diagram illustrating the structural geological evolution in the Kangerlussuaq area. The first deformational phase is F1 folding, which is intruded by Kangâmiut dykes during an extensional strain regime. The next phase is the D2 ductile deformation phase, generating large-scale NNW-plunging F2 folds, together with the syn-tectonic semi-ductile shear zones trending E-W and dipping towards $\mathrm{N}$, and showing a dextral sense of shear. The onset of brittle deformation is marked by thrust faults trending ENE-WSW creating thrust sheets with a hanging wall thrusted towards SSE. Brittle systems 3 (green, trending SE-NW), 5 (blue, trending SW-NE) and 6 (grey, trending N-S) cross-cut the aforementioned structures in different orientations.

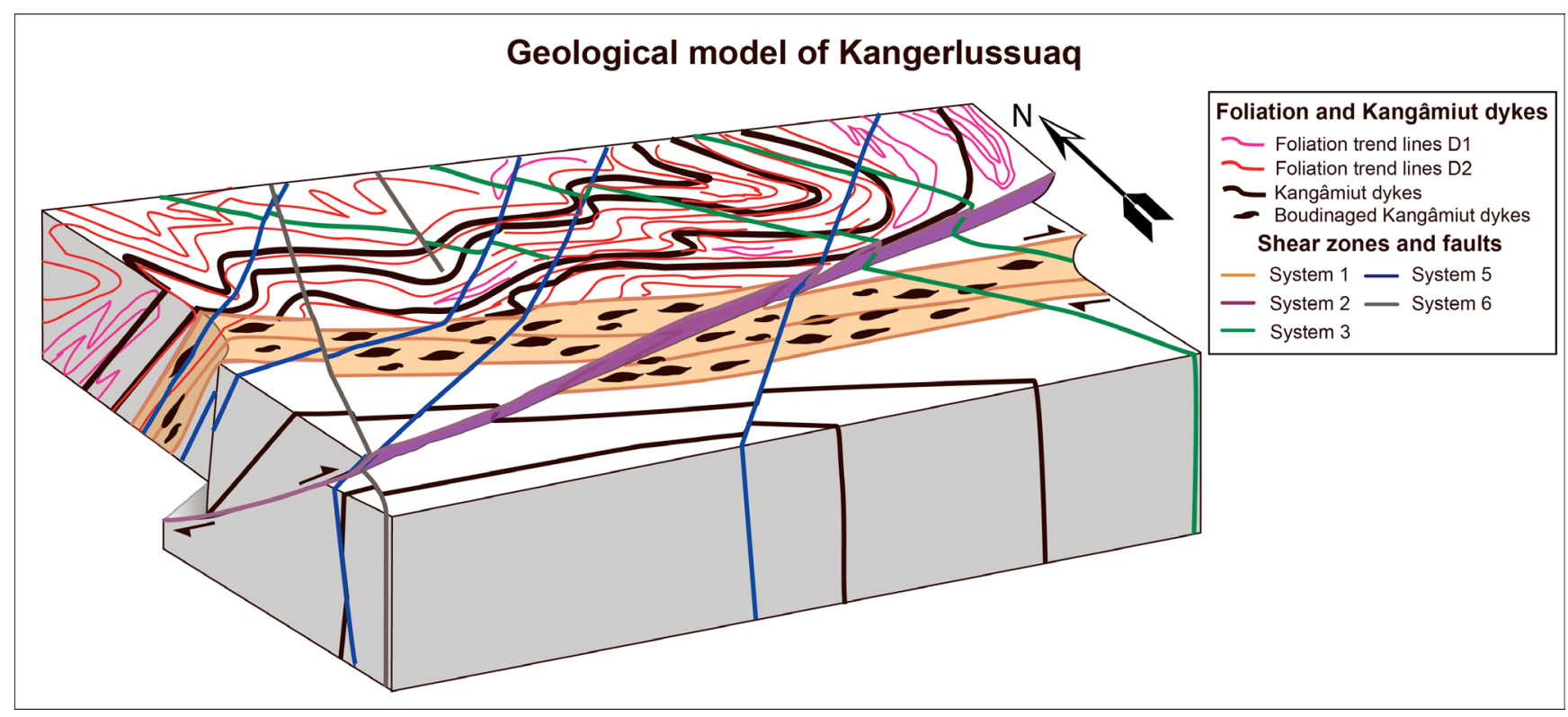

\section{Discussion}

Since no radiometric age dating has been performed in the area, the absolute ages of the different types of ductile and brittle deformations are uncertain. However, coupling with other areas within the 
orogen is suggested, comparing the individual types of deformation that each phase shows and recognising similar structures within the Nagssugtoqidian orogen in West Greenland (e.g., Garde and Hollis [1] and van Gool et al. [2] in Table 1).

Table 1. Geological history of the Kangerlussuaq area. * Based on Garde and Hollis [1] and van Gool et al. [2].

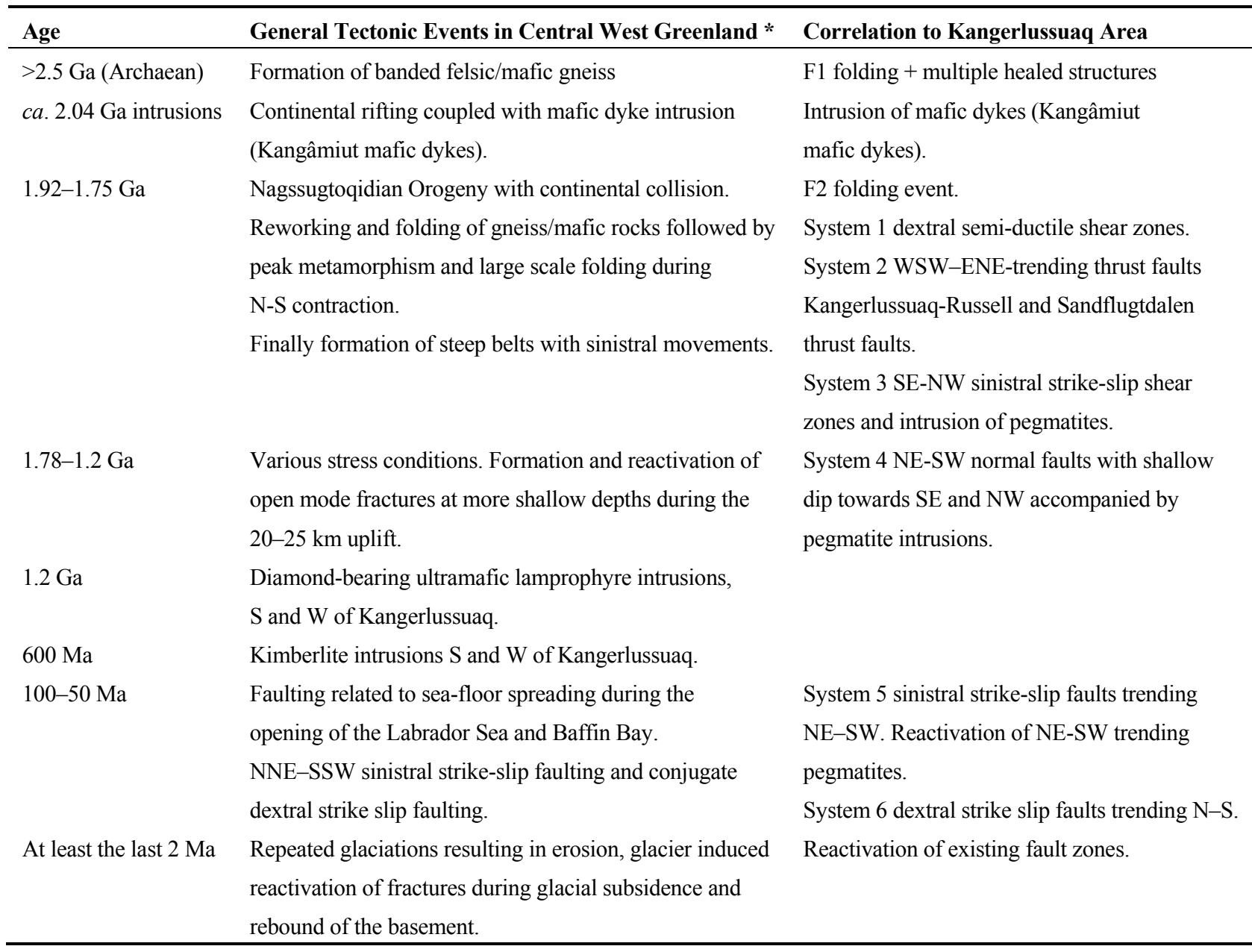

D1 is interpreted to be Archaean in age and belongs to a deformation and metamorphic event occurring soon after the emplacement of the protolith at 2.81 and $2.72 \mathrm{Ga}[11,12]$, while D2 is younger than the 2.05-2.04 Ga Kangâmiut dyke swarm [21]. This is evident because the Kangâmiut dyke swarm was folded during the D2 deformation phase. The F2 folds are interpreted to be a contemporary event with the system 1 shear zones and to be coupled with the main collision stage during the Nagssugtoqidian orogeny between 1.92 and $1.75 \mathrm{Ga}$ [1]. Van Gool et al. [2] described isoclinal folds (F2) that deform both the large-scale tectonic contacts and S1 fabrics, forming a second generation of high-temperature structures. They concluded that the F2 folds are not consistently oriented and their kinematics are not known. Some appear directly related to thrusting, whereas others deform the thrust-related foliation, and they probably include several generations of folding. Similar shearing in high-strain, low-angle shear zones that are connected to folding has been described further north in the Norder Strømfjord area by Passchier et al. [31] and Manatschal et al. [32]. These shear zones, which both cut and are folded by folds, have a consistent top-to-the-east kinematic framework, when they are unfolded back to a shallowly dipping orientation. Mineral lineations and fold axes occur in parallel. Manatschal et al. [32] argued that 
these shear zones indicate an east-vergent extensional regime based on the truncation of the Ussuit unit in some of the thrust sheets. This combination of coeval folding and shearing appears best interpreted as continued, post-collisional north-south convergence, in which crustal thickening was compensated by east-west escape or collapse [2].

The next phase of deformation (D3) is related to system 2 (e.g., the Kangerlussuaq-Russell thrust fault and Sandflugtdalen thrust fault), which thrust the folded and sheared rock towards SSE-SE, towards the foreland of the Atlantic craton. These thrusts have later been reactivated with dextral strike-slip movement. Further north, the folding event is due to $\mathrm{N}-\mathrm{S}$ compression, which is compatible with south-directed thrusting in the Ikertôq thrust zone approximately $30 \mathrm{~km}$ north of our study area. The thrusting towards SE in our area indicates a more NW-SE-directed compression, which may also indicate the strain direction causing the reactivated dextral shear sense in the more ductile system 1 shear zones. The variation in deformation style in response to the same regional stress field probably reflects different levels of crustal exposure across the orogen today. The metamorphic peaks in the foreland postdate the metamorphic peak in the central parts, presumably indicating that crustal thickening was ongoing along the flanks of the Nagssugtoqidian orogen after it ceased in the central parts [2].

Kolb [8] described similar changing of the stress field for the Nagssugtoqidian orogen in Southeast Greenland, where the orientation of the stress field during later stages of collision (D2) had a NE-SW direction. This was followed by D3 deformation, with southeastward juxtaposition of the Schweizerland Terrane, which required rotation of the regional stress field to a NW-SE orientation either at 1820 or $1740 \mathrm{Ma}$, and could well be coupled to the D3 thrusting in our area.

Accordingly, it is interpreted that the F2 folding was contemporaneous with the system 1 shear zones, and the D3 thrust zones post-date the two earlier events during the Nagssugtoqidian orogeny. The strain direction in our study area points at a NW-SE-directed contraction, which would indicate that it has been shifted since the onset of the F2 folding event, suggesting a more NE-SW-directed contraction for the folding. However, the system 1 shear zones and the system 2 thrust zones can be found in the same stress regime, simply reflecting different levels of crustal exposure indicative of the nature of their respective deformation. The D3 thrust zones are defined to be the youngest, as they cross-cut these earlier deformational structures.

The timing of the system 3, 4, 5 and 6 lineaments is highly speculative, but because their character is more brittle, they might be related to tectonic events taking place after the orogeny. The youngest (type 6 lineaments) and hence most brittle deformations may be related to the opening of the North Atlantic Ocean, the Labrador Sea and the Baffin Bay over the last $100 \mathrm{Ma}$ [30].

The reworked felsic banded gneisses and mafic garnet-rich orthogneisses found in the study area are presumed to be Archaean in age, since similar types of rocks have been described by Kalsbeek and Nutman [11] further to the west of our study area. Since no detailed petrological description or geochemistry has been performed on our rocks, their coupling to the regional context and linking of their origin to tectonic evolution in the area is not possible.

\section{Summary}

The results of a detailed structural investigation of lineament zones revealed from remote sensing of geophysical and topographic data and aerial photo interpretation, together with detailed geological 
mapping at key locations facilitated the construction of a tectonic structural model describing the geological development of the Kangerlussuaq area. The area has undergone several episodes of deformation, which have been compiled into an event succession that recognizes eight tectonic events overprinting each other: Two stages of folding (F1 and F2) have been identified along with one major episode of intrusion of the Kangâmiut mafic dyke swarm at $2.05 \mathrm{Ga}$, and six pronounced faulting/shearing events post-dating the Kangâmiut dykes extending from ductile deformation shearing events to brittle deformation with extensive faulting, covering both the collisional and post-collisional tectonic history of the area.

Two types of lineaments are prominent in the Kangerlussuaq area; a semi-ductile type trending E-W with a dextral sense of shear and two pronounced lineaments outlining the Kangerlussuaq-Russell thrust fault and the Sandflugtdalen thrust fault.

The absolute ages of the different types of ductile and brittle deformations are uncertain because of a lack of radiometric ages. The E-W-trending semi-ductile shear zones and the Kangerlussuaq-Russell and Sandflugtdalen thrust faults are interpreted to be related to different tectonic phases during the formation of the Nagssugtoqidian orogen, together with the previously occurring F2 folding event. However, the exact relation between the F2 folding system and the system 1 shear zones remains to be determined. The system 3 and 4 semi brittle lineaments may be of intermediate ages related to later tectonic events. System 4, in particular, is related to extensional stress regimes accompanied by pegmatite intrusions. The youngest and hence most brittle deformations, systems 5 and 6 , may be related to the opening of the North Atlantic Ocean, the Labrador Sea and the Baffin Bay over the last $100 \mathrm{Ma}$. An event succession model has been constructed and correlation with the regional geological event model has been attempted.

Finally, radiometric age determinations are suggested, particularly of the available felsic rocks together with cross-cutting pegmatites, and of pseudo-tachylites and other fault-related rocks, in order to better constrain the tectonic history. These age determinations, coupled with detailed petrological description and geochemistry, would be vital to resolve the tectonic evolution of the Kangerlussuaq area, and would thus be an important addition to understanding of the geological evolution of central West Greenland.

\section{Acknowledgments}

The work was funded by the Swedish, Finnish and Canadian nuclear waste management organizations and carried out by participants from GTK, GEUS, SKB, Posiva and NWMO. Special gratitude is expressed to whole GAP Subproject $\mathrm{C}$ field team for their contribution and endless efforts during several field seasons in the Kangerlussuaq area. The authors also wish to give a special thanks to Lillemor Claesson Liljedahl and Timo Ruskeeniemi for constructive comments on the early versions of the manuscript. The authors wish to thank both reviewers (Dr. Iain Neill and an anonymous reviewer) of the paper, who enhanced the final manuscript before publication.

\section{Author Contributions}

Both authors contributed equally to the paper. 


\section{Conflicts of Interest}

The authors declare no conflict of interest.

\section{References}

1. Garde, A.A.; Hollis, J.A. A buried Palaeoproterozoic spreading ridge in the northern Nagssugtoqidian orogen, West Greenland. In The Evolving Continents: Understanding Processes of Continental Growth; Special Publications Volume 338; Kusky, T.M., Zhai, M.-G., Xiao, W., Eds.; Geological Society of London: London, UK, 2010; pp. 213-234.

2. Van Gool, J.A.M.; Connelly, J.N.; Marker, M.; Mengel, F.C. The Nagssugtoqidian orogen of West Greenland: Tectonic evolution and regional correlations from a West Greenland perspective. Can. J. Earth Sci. 2002, 39, 665-686.

3. Ramberg, H. On the petrogenesis of the gneiss complexes between Sukkertoppen and Christianshaab, West Greenland. Meddelelser fra Dansk Geologisk Forening 1949, 11, 312-327.

4. Escher, A.; Pulvertaft, T.C.R. Rinkian mobile belt of West Greenland. Geol. Greenl. 1976, 1976, 104-119.

5. Marker, M.; Mengel, F.; van Gool, J. Evolution of the Palaeoproterozoic Nagssugtoqidian orogen: DLC investigations in West Greenland. Rapp. Grønlands. Geol. Unders. 1995, 165, 100-105.

6. Connelly, J.N.; Thrane, K.; Krawiec, A.W.; Garde, A.A. Linking the Palaeoproterozoic Nagssugtoqidian and Rinkian orogens through the Disko Bugt region of West Greenland. J. Geol. Soc. 2006, 163, 319-335.

7. Harper, J.; Hubbard, A.; Ruskeeniemi, T.; Liljedahl, L.C.; Lehtinen, A.; Booth, A.; Brinkerhoff, D.; Drake, H.; Dow, C.; Doyle, S.; et al. The Greenland Analogue Project Yearly Report 2010; Report SKB R-11-23; Swedish Nuclear Fuel and Waste Management Co: Stockhom, Sweden, 2011.

8. Kolb, J. Structure of the Palaeoproterozoic Nagssugtoqidian Orogen, South-East Greenland: Model for the tectonic evolution. Precambrian Res. 2014, 255, 809-822.

9. Kalsbeek, F.; Taylor, P.N.; Henriksen, N. Age of rocks, structures, and metamorphism in the Nagssugtoqidian mobile belt, West Greenland-Field and Pb-isotopic evidence. Can. J. Earth Sci. 1984, 21, 1126-1131.

10. Kalsbeek, F.; Pidgeon, R.T.; Taylor, P.N. Nagssugtoqidian mobile belt of West Greenland: Cryptic 1850Ma suture between two Archaean continents-Chemical and isotopic evidence. Earth Planet. Sci. Lett. 1987, 85, 365-385.

11. Kalsbeek, F.; Nutman, A.P. Anatomy of the early Proterozoic Nagssugtoqidian orogen, West Greenland, explored by reconnaissance SHRIMP U-Pb dating. Geol. Soc. Am. 1996, 24, 515-518.

12. Connelly, J.N.; Mengel, F.C. Evolution of Archaean components in the Palaeoproterozoic Nagssugtoqidian Orogen, West Greenland. Geol. Soc. Am. Bull. 2000, 112, 747-763.

13. Windley, B.F. Primary quartz ferro-dolerite/garnet amphibolite dikes in the Sukkertoppen region of West Greenland. In Proceedings of Mechanism of Igneous Intrusion, Liverpool, UK, 9-11 January 1969; pp. 79-92.

14. Escher, A.; Escher, J.C.; Watterson, J. The reorientation of the Kangâmiut dike swarm, West Greenland. Can. J. Earth Sci. 1975, 12, 158-173. 
15. Escher, A.; Sørensen, K.; Zeck, H.P. Nagssugtoqidian Mobile Belt in West Greenland. Geol. Greenl. 1976, 1976, 103.

16. Korstgård, J.A. Metamorphism of the Kangâmiut dykes and the metamorphic and structural evolution of the southern Nagssugtoqidian boundary in the Itivdleq-Ikertôq region, West Greenland. Rapp. Grønlands. Geol. Unders. 1979, 89, 63-75.

17. Bridgwater, D.; Mengel, F.; Fryer, B.; Wagner, P.; Hansen, S.C. Early Proterozoic Mafic Dykes in the North Atlantic and Baltic Cratons: Field Setting and Chemistry of Distinctive Dyke Swarms. In Early Precambrian Processes; Special Publications Volume 95; Coward, M.E., Ed.; Geological Society of London: London, UK, 1995; pp. 193-210.

18. Nutman, A.P.; Kalsbeek, F.; Marker, M.; van Gool, J.A.M.; Bridgwater, D. U-Pb zircon ages of Kangâmiut dykes and detrital zircons in metasediments in the Palaeoproterozoic Nagssugtoqidian Orogen (West Greenland). Precambrian Res. 1999, 93, 87-104.

19. Connelly, J.N.; van Gool, J.A.M.; Mengel, F.C. Temporal evolution of a deeply eroded orogen: The Nagssugtoqidian Orogen, West Greenland. Can. J. Earth Sci. 2000, 37, 1121-1142.

20. Cadman, A.C.; Tarney, J.; Bridgwater, D.; Mengel, F.; Whitehouse, M.J.; Windley, B.F. The petrogenesis of the Kangâmiut dyke swarm, W. Greenland. Precambrian Res. 2001, 105, 183-203.

21. Mayborn, K.R.; Lesher, C.E. Origin and evolution of the Kangâmiut mafic dyke swarm, West Greenland. Geol. Surv. Den. Greenl. Bull. 2006, 11, 61-86.

22. Taylor, P.N.; Kalsbeek, F. Dating the metamorphism of Precambrian marbles: Examples from Proterozoic mobile belts in Greenland. Chem. Geol. Isot. Geosci. Sect. 1990, 86, 21-28.

23. Willigers, B.J.A.; Krogstad, E.J.; Wijbrans, J.R. Comparison of thermochronometers in a slowly cooled granulite terrain: Nagssugtoqidian Orogen, West Greenland. J. Petrol. 2001, 42, 1720-1749.

24. Connelly, J.N.; Thrane, K. Rapid determination of Pb isotopes to define Precambrian allochthonous domains: An example from West Greenland. Geology 2005, 33, 953-956.

25. Garde, A.A.; Hollis, J.A.; Mazur, S. Palaeoproterozoic greenstones and pelitic schists in the northern Nagssugtoqidian orogen, West Greenland: Evidence for a second subduction zone? In Proceedings of Geological Association of Canada-Mineralogical Association of Canada (GAC-MAC) Annual Meeting, Yellowknife, Canada, 23-25 May 2007; Volume 32, p. 30.

26. St.-Onge, M.; van Gool, J.A.M.; Garde, A.A.; Scott, D.J. Correlation of Archaean and Palaeoproterozoic units between northeastern Canada and western Greenland: Constraining the pre-collisional upper plate accretionary history of the Trans-Hudson orogen. In Earth Accretionary Systems in Space and Time; Special Publications Volume 318; Cawood, P.A., Kröner, A., Eds.; Geological Society of London: London, UK, 2009; pp. 193-235.

27. Garde, A.A.; Marker, M. Geological Map of Greenland: Sandflugtdalen-Nuussuaq; Geological Survey of Denmark and Greenland: Copenhagen, Denmark, 2010; Map Sheet, 1:500000.

28. Klint, K.E.S.; Engström, J.; Parmenter, A.; Ruskeeneimi, T.; Liljedahl, L.C.; Lehtinen, A. Lineament mapping and geological history of the Kangerlussuaq region, southern West Greenland. Geol. Surv. Den. Greenl. Bull. 2013, 28, 57-60.

29. Grocott, J. Shape fabrics and superimposed simple shear strain in a Precambrian shear belt, West Greenland. J. Geol. Soc. 1979, 136, 471-488. 
30. Wilson, R.W.; Klint, K.E.S.; van Gool, J.A.M.; McCaffrey, K.J.W.; Holdsworth, R.E.; Chalmers, J.A. Faults and fractures in central West Greenland: onshore expression of continental break-up and sea-floor spreading in the Labrador-Baffin Bay Sea. Geol. Surv. Den. Greenl. Bull. 2006, 11, 185-204.

31. Passchier, C.W.; den Brok, S.W.J.; van Gool, J.A.M.; Marker, M.; Manatschal, G. A laterally constricted shear zone system-The Nordre Strømfjord steep belt, Nagssugtoqidian Orogen, W. Greenland. Terra Nova 1997, 9, 199-202.

32. Manatschal, G.; Ulfbeck, D.; van Gool, J.A.M. Change from thrusting to syn-orogenic extension in a mid-crustal level: An example from the Ussuit area, Nagssugtoqidian Orogen, West Greenland. Can. J. Earth Sci. 1998, 35, 802-819.

(C) 2014 by the authors; licensee MDPI, Basel, Switzerland. This article is an open access article distributed under the terms and conditions of the Creative Commons Attribution license (http://creativecommons.org/licenses/by/4.0/). 